\title{
DFID INTERIM STRATEGY FOR AFGHANISTAN 2005/6
}

\section{Summary}

- This interim strategy sets out DFID's priorities and spending plans for 2005/6 (1384). Publication of a longer-term DFID strategy has been postponed until 2006 so it can be developed alongside the Afghan Government's National Development Strategy, as well as a new overall UK strategy.

- Afghanistan has made remarkable progress since 2001. However it remains one of the world's poorest countries, economically and politically fragile, and heavily dependent on international military, financial and technical assistance. Economic growth has been strong. But the economy is dominated by the illegal opium industry, which fuels insecurity, corruption and indebtedness. Continued improvements in security and the rule of law are critical for progress. Institutional reform is underway, but Afghan capacity is still very limited, and will take many years to build.

- The Afghan Government is working on a National Development Strategy, which will prioritise investments needed to promote growth and reduce poverty and insecurity. It needs donor assistance to implement this strategy. Yet three-quarters of aid does not go through Government systems, making it difficult for the Government to coordinate assistance or be accountable. Development aid is nearly ten times Government revenue, but is dwarfed by international military assistance.

- Afghanistan remains one of the UK's top priorities, given the urgent need to tackle terrorism and extremism, address poverty and injustice, and make progress on counter-narcotics (where we are G8 lead nation). DFID's work is already well coordinated with other parts of the UK Government in Afghanistan. We aim to improve this further, and maintain flexibility, as overall UK strategy is developed.

- DFID's programme is evolving from a humanitarian to a developmental focus. It prioritises creating the conditions for sustainable poverty reduction in the medium to long-term. The highest immediate priority is to stabilise the country, to ensure the Government is able to deliver services nationwide, and establish the rule of law within a democratic political system that safeguards human rights.

- The programme has three focal areas: i) livelihoods; ii) economic management and aid effectiveness; iii) state-building. Building Government ownership and capacity, collaboration with other donors, and work on counter-narcotics run across all three areas. DFID supports Afghan leadership by putting more than $70 \%$ of our funds through the national budget and national programmes. We are exploring how we can support the UK's increasing focus on Helmand province in 2006.

- DFID's programme has grown substantially since 2001. Further increases are planned in future years. We will spend at least $190 \mathrm{~m}(\$ 160 \mathrm{~m})$ in $2005-6$. Half of this will go on alternative livelihoods. We will develop a more rigorous approach to monitoring the development outcomes to which our spending contributes. Where possible, we will do this jointly with the Government and other donors.

- The main risks to us achieving these objectives are a deterioration in security, the opium economy undermining development, and limited Afghan Government capacity. If these risks can be addressed over time, the prospects for a viable state and gradual poverty reduction in Afghanistan are good.

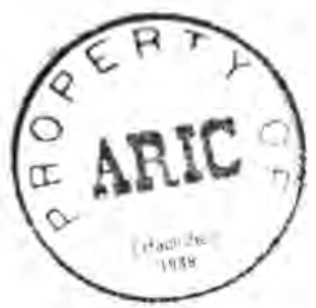




\section{The development context}

1.1 After more than twenty years of conflict and isolation, Afghanistan has made rapid progress over the last $3 \frac{1}{2}$ years. Since the fall of the Taliban in late 2001 , it has recovered from being a failed state to establish a new constitution, a government committed to political, economic and social development, and a democratically elected President. Over 60,000 former combatants have been disarmed, and 3.5 million refugees have returned home. The number of functioning health clinics has increased by $60 \%$. Nearly two thousand schools have been built or rehabilitated, and over 5 million children are in school - more than a third of them girls. These are remarkable achievements.

1.2 Afghanistan's challenges remain formidable. The political consensus is unstable, with continued insurgency in parts of the country and terrorism an ever-present threat. Economic progress is patchy, with overly high expectations of how long reconstruction will take. Governance problems - notably corruption, limited capacity and dysfunctional institutions - affect everything. The drugs trade is a major threat to the rule of law. Afghanistan's security, reconstruction and political challenges are inextricably interlinked. The risks of failure are real and worrying.

1.3 After decades of insecurity, destruction and under-investment, poverty is deeply entrenched. Afghanistan is off-track on all the Millennium Development Goals (MDGs), and has some of the worst human development indicators in the world, ranking 173 out of 178 countries on the 2004 UNDP Human Development Index ${ }^{1}$. Average income is about $\$ 300$ per person (including from opium, which disproportionately benefits a minority). $71 \%$ of Afghans over the age of 15 cannot read and write, rising to $92 \%$ for rural women, and three out of five girls don't go to school. Life expectancy at birth is 45 years, and at least one in five children dies before the age of five. The maternal mortality rate may be the highest in the world: one woman dies from pregnancyrelated causes approximately every thirty minutes, and in rural areas fewer than $10 \%$ of women give birth in a health facility. Large parts of Afghanistan's infrastructure are in tatters; in more remote areas, it has never been developed. The vast majority of Afghans do not have access to electricity or safe water. For some mountainous villages, the nearest road is two weeks' walk away. Geographical variations in poverty are not well understood, but in some provinces it is likely that over $90 \%$ of the population is poor. Reliable basic data - including on population -is difficult to collect, with no census since 1978 .

1.4 Sustained economic growth is needed to address these levels of poverty. Afghanistan's economy performed strongly from a very low base after 2001 , with growth of $29 \%$ in $2002,16 \%$ in 2003 and $8 \%$ in 2004. Excellent rains are likely to lead to bumper harvests (including poppy) and double digit growth in 2005. The Government's Securing Afghanistan's Future report assumes a $9 \%$ annual non-drug growth rate over the next ten years, which would be enough to deliver per capita growth of $3 \%$ even with the elimination of the drug economy - enough to increase per capita income to $\$ 500$ by 2015 , and enable the Government to cover its recurrent costs. This is certainly possible given Afghanistan's natural assets, low rates of productivity and sustained high levels of international aid. But it will become increasingly difficult to maintain these high growth rates over time without a better environment for the private sector. 
1.5 Macro-economic management has been good. But with $80-90 \%$ of all activity in the informal economy, the Government finds it very difficult to collect sufficient tax to finance public expenditure. At less than 5\% of GDP, Afghanistan's domestic revenue is one of the lowest in the world. Although rising, it is not yet sufficient to pay for even half the Government recurrent budget. Domestic revenue in $2005 / 6$ is expected to be around $\$ 330 \mathrm{~m}$. Foreign aid is expected to be over $\$ 3$ billion. Afghanistan remains heavily dependent on external assistance ${ }^{2}$, and will be for many years. Increasing domestic revenue quickly is a critical task.

1.6 There is little consensus on what will drive growth in the medium-term. Agriculture contributes over half of legal GDP, but (with the exception of opium) has largely lost its previous large global export market. Although it will remain critical for poverty reduction over the next few years, agriculture is unlikely to drive high rates of growth over the long-term, even with the improvements in irrigation, production techniques, credit, agribusiness development and market access which are badly needed. Construction is creating a lot of short-term growth; this will tail off but is likely to remain strong. Afghanistan also has export potential in several sectors including agriculture, mining, gas and traditional goods such as carpets. But foreign investment to develop these industries will be difficult to attract until security, physical infrastructure and the business environment improve. The same applies to tourism and transit trade with neighbouring countries, both of which have considerable longer-term potential if Afghanistan can develop better regional economic cooperation with its neighbours. Longer-term growth will also require sustained investment in Afghanistan's very limited human capacity.

1.7 Meanwhile, the opium trade dominates the Afghan economy, contributing $35-40 \%$ of total GDP in 2004. Poppy is the most profitable crop for farmers, and provides income for many poor labourers; no alternative can compete economically, and poppy has often been a low risk choice. But it fuels insecurity, corruption and indebtedness, and represents a major challenge to poverty reduction. Increased Afghan political will to tackle the problem has been evident in the last year. Self-restraint in planting poppy is expected to reduce cultivation in 2005 in most provinces (although yields may increase given good rains and reduced disease). But cultivation is moving to new provinces, and without a sustained and integrated Afghan-led effort to consolidate progress, may increase further in 2006. A rapid contraction in the opium economy threatens the livelihoods of some of the rural poor. The conditions for alternative livelihoods are being developed, but take time to become sustainable and widespread. Progress is unlikely to be linear or uniform.

1.8 Increasing criminality, warlordism and the continued presence of the Taliban and Al-Qaeda elements is an ongoing threat to both political transition and economic development. Reflecting the importance of security as a precondition for sustainable progress on all other MDGs, the Government of Afghanistan is adopting a special MDG on enhancing security. Progress in reforming the security sector has been substantial but uneven. A new army is being built from scratch, and major reform of the police is underway. Both will take years of investment and training before foreign troops are not needed to maintain basic security. Progress in the justice sector has been difficult, delaying creation of a functioning law and order system. Disarmament, Demobilisation and Reintegration (DDR) of former combatants has made good progress, but a large number of illegal armed groups remain. A new reconciliation programme has the potential to improve security but is very sensitive. Much work needs to be done in building regional relationships.

\footnotetext{
${ }^{2}$ The Core Budget $-34 \%$ of the total National Budget - is nearly $80 \%$ funded by internationail assistance. The Externai Budget, funded entirely by international assistance, represents $66 \%$ of the National Budget. (Source; Overview of the 1384 Budget, Ministry of Finance, 2005 ADF papers).
} 
1.9 Progress has been made in re-establishing state institutions. But these are weak and fragmented, particularly outside Kabul, where local government structures and roles are poorly developed, and staff illiteracy is very high. The nature and number of government bodies needs to be examined critically for both efficiency and fiscal sustainability. There are chronic problems of human capacity, exacerbated by international organisations hiring many of the best Afghan staff; with most civil servants getting paid $\$ 40-50$ per month, unreformed ministries find it hard to recruit and retain skilled staff. The negative impact of widespread corruption and patronage at all levels needs to be addressed. These are major challenges to poverty reduction and sustainable development. Sustainable and affordable public administration reform will take many years. Popular expectations are high, as is the risk that Government institutions cannot deliver - and lose credibility. The election of a Parliament in September 2005 may exacerbate these tensions.

\section{Strategies for assistance}

\section{a) Government of Afghanistan (GoA)}

2.1 The GoA prepared a National Development Framework (NDF) in April 2002, and an agenda for growth and recovery - Securing Afghanistan's Future (SAF) - in March 2004. These provide a good overview of Afghanistan's multiple needs, and a structure for addressing them through three pillars of investment - Human and Social Capital, Physical Infrastructure/Natural Resources, and Security and the Private Sector. But there is no clear consensus on how to sequence and prioritise development interventions to achieve national goals. In recognition of this, the Government is now preparing an Afghan National Development Strategy (ANDS).

2.2 The ANDS will be GoA's overarching strategy for promoting growth and reducing poverty and vulnerability. It will provide the framework for the development of Government policies, and guide the allocation of resources and programmes towards ANDS goals. The ANDS is being prepared in two phases: (i) an interim version (I-ANDS) will be ready by December 2005; (ii) a final ANDS should be completed by the end of 2006. An I-ANDS with a clear framework for donor coordination and harmonisation will provide an opportunity for donors to improve the effectiveness of their development assistance, divide their labour more efficiently, and align more coherently behind the Government's priorities.

\section{b) Donors}

2.3 Donor commitment to Afghanistan remains high - for now. Donors committed $\$ 5.2$ billion at the Tokyo conference in 2002, rising to $\$ 8.2$ billion over three years in Berlin in 2004. But disbursements of aid pledges have been slow; half of committed funds are unspent. Reasons for slow disbursement include delays to project and programme design, lack of capacity within Government, and security. Many donors have very few staff in Kabul. Even so, aid per capita has risen from just $\$ 5$ per capita in 2000 to around $\$ 50$ per capita in 2003 . Compared to other countries affected by recent humanitarian/conflict crises, this is quite modest ${ }^{3}$, but MDG aid allocation models suggest Afghanistan is generously aided. The biggest donors are the USA (by far, with a $\$ 1.6$ billion aid commitment in 2005), the World Bank, the Asian Development Bank, the European Commission, Japan and the UK. UNAMA (the United Nations Assistance Mission in Afghanistan) has the biggest international presence, covering political and developmental support. Development aid is nearly ten times government revenue, but is dwarfed by international military assistance, which will cost more than twice the total value of the Afghan economy in 2005.

\footnotetext{
s Aid to Palestine in 2002 was estimated to be $\$ 500$ per capita; to Bosnia-Herzegovina in $1999 \$ 261$; and to Mozambique in $2002 \$ 111$. Afghanistan Update, Aid to Afghanistan - building the momentum?
} 
2.4 Nearly three-quarters of aid does not go through Government systems, making it difficult for the Government to coordinate assistance or be accountable to the Afghan people. UN agencies and private companies account for about $85 \%$ of the rest. NGOs have played a major role in the delivery of basic services for many years, but are now viewed with scepticism by some in Government, often unfairly. A Government/donor Consultative Group mechanism exists to coordinate assistance, but is patchy. A G8 lead nation system for key security issues has had mixed success. Many donor nations retain strong bilateral political interests, which often override the need to harmonise assistance and align it behind Government leadership.

2.5 The international community's approach to Afghanistan since the end of 2001 has been driven by the Bonn Agreement, which set out the key milestones (particularly political) in recreating a legitimate Afghan Government. Successful parliamentary and provincial elections in September 2005 will effectively mark the end of the Bonn process. But the international community and GoA recognise that international support of an unusual kind, both in nature and scale, will still be needed for some time to come. A new compact between Afghanistan and the international community is now being developed. This recognises the Afghan Government's full sovereignty, but sets out ways in which the international community can help consolidate that sovereignty through military, political and economic assistance, including a continuing major role for the United Nations.

\section{c) UK}

2.6 Afghanistan remains one of the UK's top priorities, given the urgent need to tackle terrorism and extremism, address poverty and injustice, and make progress on counter-narcotics (where we are G8 lead nation). Signature of the "Enduring Relationship" agreement in July 2005 demonstrated the UK's sustained commitment to Afghanistan. The UK's overall long-term goal is:

"a stable and secure Afghanistan restored to its rightful place in the community of nations; with a self-sustaining economy, strong institutions and a broad-based, multi-ethnic regime committed to eradicating terrorism and eliminating opium production; reducing poverty; respecting human rights; and honouring Afghanistan's other international obligations".

2.7 DFID's programme contributes to this UK goal through working within our particular mandate of poverty reduction. We also contribute expertise in economic, institutional, and social analysis to wider UK policy and operations where these are relevant to poverty reduction. We have aligned our support behind overall UK priorities, notably through a strong focus on alternative livelihoods in support of the UK's G8 lead nation status on counter-narcotics, our work through Provisional Reconstruction Teams (PRTs), and our involvement in a cross-Government programme to reduce the risk of conflict ${ }^{4}$.

2.8 DFID's work is already well coordinated with the activities of other parts of the UK Government in Afghanistan. We work very closely with the British Embassy, particularly on counter-narcotics. We have development advisers in the British Embassy Drugs Team, the Afghan drugs unit in London, and the UK-led PRT in Mazar-e-Sharif. We plan to intensify our advisory role with the UK military by putting development advisers in the new UK-led PRT in Helmand province and NATO ISAF HQ in late 2005 , and to respond flexibly to overall UK priorities.

2.9 The UK is committed to ensuring our contribution to Afghanistan continues to be coherently managed across the different strands of our activity. DFID will work closely with other Government Departments as a more integrated strategy, and an approach to measuring progress against it, are developed.

\footnotetext{
* The Global Global Conflict Prevention Pool, managed by the FCO but also involving DFID and the MoD.
} 
2.10 DFID last published a strategy for Afghanistan in 2003. This has been out of date for some time. Publication of a longer-term DFID strategy has been postponed until 2006 so it can be developed alongside, and aligned with, GoA's National Development Strategy, as well as overall UK strategy. In doing so we will take account of the Afghan Government's views on how our non-budgetary aid should be used.

2.11 This interim strategy sets out DFID's priorities and spending plans for 2005/6 (the Afghan year 1384). We already have committed plans to spend in full our budget of $£ 90 \mathrm{~m}$ for $2005 / 6$, and we have a strong pipeline for $2006 / 7$. We thus have very limited flexibility to fund completely new activities until April 2006. But we will maintain some flexibility to reallocate resources within programmes. During this period we are concentrating on:

i) overseeing implementation of our existing activities

ii) developing better monitoring tools to track impact

iii) helping the Government develop its own national strategy and sectoral plans

iv) contributing to policy dialogue among donors on improving aid effectiveness

v) contributing a development perspective to the evolution of overall UK strategy

vi) beginning to design further spending plans for $2006 / 7$ and beyond

vii) realigning our human resources to better deliver our objectives.

\section{Overview of DFID programme}

3.1 In line with Afghanistan's needs, DFID's programme has evolved from a mainly humanitarian focus after the fall of the Taliban. The highest immediate priority is to stabilise the country, to ensure the Government is able to deliver services nationwide, and establish the rule of law within a democratic political system that safeguards human rights. Without this stability, sustainable poverty reduction is unlikely to succeed. Our programme is thus now focused primarily on creating the conditions for sustainable development and poverty reduction. This is consistent with the strategic path set out in Securing Afghanistan's Future towards a vision of Afghanistan in 2015 as "a self-sustaining state, with the capacity to meet basic social needs and embark on the process of poverty eradication".

3.2 This path recognises that Afghanistan is unlikely to achieve any of the MDGs by 2015. The goal is to make it possible for Afghanistan to participate on a normal basis in the international development system, and become a low income country with a legal economy, able to meet the most basic of social needs, and with aspirations to move into low-middle income status and begin to achieve the MDGs over the following decade.

3.3 The DFID programme for $2005 / 6$ supports this aim and therefore is not explicitly directed at progress towards the MDGs in the short-term. It prioritises the enabling actions needed for sustainable poverty reduction to take place in the medium to long term. For example, although our support to the Government's budget enables Government schools and clinics to operate, we do not work directly in the education or health sectors. This is partly a reflection of the choices made by other donors, our perceived comparative advantage, and the need to focus our activities on a small number of areas. It is more driven by recognition of the continuing fragility of the Afghan state, and the importance of mitigating the biggest risks of its collapse, given the impact this would have on poverty. Nonetheless, many of our activities do have a significant impact on poverty in the short-term, and as Afghanistan becomes more stable, we plan to evolve our programme further to a more direct focus on the delivery of services and pro-poor economic growth needed to achieve the MDGs. 
3.4 The programme has three focal areas: i) livelihoods; ii) economic management and aid effectiveness; iii) state-building. Progress on all three is essential for creating the conditions for longer-term development, and avoiding continued dominance of the opium economy, a Government with insufficient revenues, and state failure due to dysfunctional institutions.

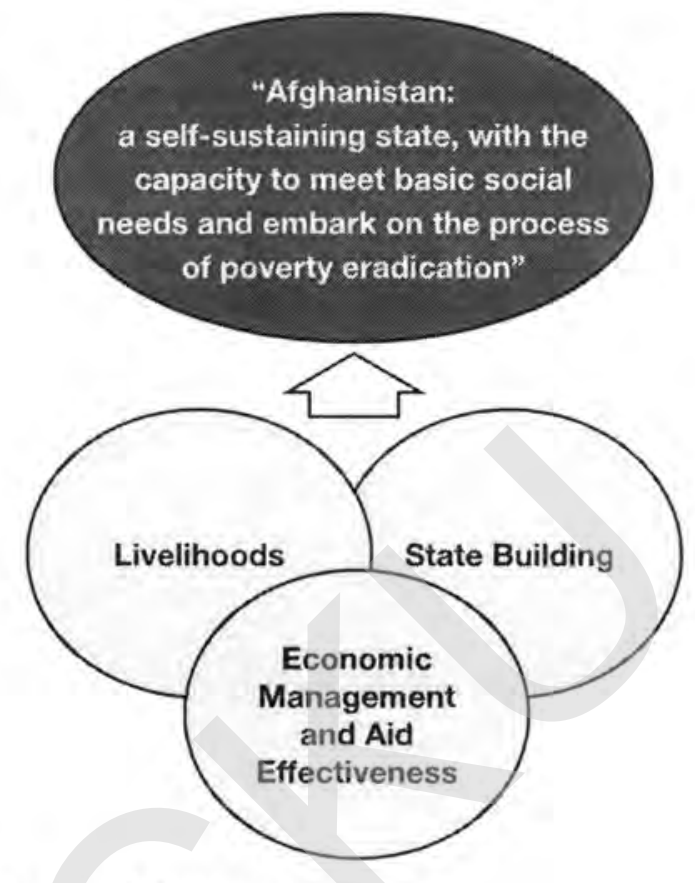

3.5 Four themes run across all three areas:

a) Building Government ownership and leadership. Over $70 \%$ of our funding goes through the core Government budget. Where we can, we mostly work directly with Government ministries rather than through parallel implementing partners. This also contributes to the second thematic objective:

b) Building Government capacity. Much of the rest of our funding goes on technical assistance to increase ministries' ability to run their own affairs more competently and independently. This is a very long-term agenda.

c) Working with other donors. Most of our programme is undertaken jointly with other donors. We will look for more opportunities to harmonise our assistance with the wider donor effort, to improve its effectiveness and reduce the transaction costs for GoA and other partners.

d) Counter-narcotics. Our primary contribution to counter-narcotics is through our livelihoods programme. But our state-building activities include strengthening the capacity of GoA's counter-narcotics institutions, and our economic management activities include supporting improved Government budgeting to recognise the central importance of success in counter-narcotics for both the Afghan and UK governments' policy objectives - and for sustainable poverty reduction.

3.6 The programme supports GoA's leadership of the development process by working mostly through the national budget and national programmes. However we will explore during 2005-6 the extent to which DFID can support the UK's increasing focus on Helmand province in 2006 . We will also maintain a secondary focus on Badakhshan province, and continue our involvement in the PRT in Kandahar. We will gradually withdraw from PRTs in Mazar-e-Sharif and Bamyan. 


\section{Focal areas for $2005 / 06$}

\section{a) Livelihoods}

4.1 SAF highlights that growth in Afghanistan's non-drug economy (of at least $9 \%$ per annum) will be needed to ensure that there is visible economic and social progress while eliminating the drug economy over time. It identifies alternative livelihoods policies, and particularly Afghanistan's agricultural sector, as "the corner stone of any successful counter-narcotics strategy". President Karzai has repeatedly stressed the importance of the counter-narcotics campaign and has specifically asked that the international community focus their support on the provision of alternative livelihoods in 2005. As the G8 lead nation on counter-narcotics, the UK has a particular responsibility to play a major role in helping the Government develop its alternative livelihoods strategy, and in financial support for its implementation.

4.2 The availability of alternative livelihoods in itself will not persuade all farmers to stop growing poppy. A successful counter-narcotics strategy needs to combine several elements, including law enforcement, the threat of eradication, alternative livelihoods, public information and action on governance. Alternative livelihoods is of most relevance to poor farmers and labourers who literally have no alternative than growing poppy if they are to make a living and pay off their debts. DFID funding is primarily targeted to these poor people, who are involved in the opium industry through need rather than greed. Without continuing rapid growth in the legal economy, the GoA's ambition to eliminate poppy production rapidly could result in a contraction of the economy and worsening poverty. This is a long-term challenge for the development of the rural economy as a whole, not just the provision of alternative livelihoods.

4.3 Between 2003-4 and 2005-6 DFID's spending on alternative livelihoods has increased by a factor of ten. DFID's livelihoods programme addresses a broad range of issues, including the development of alternative crops and access to agricultural inputs and services. We are also looking more broadly at issues such as rural credit and opium debt, community and skills development, market access, small rural enterprises, institutional development, and improved provincial planning. A key component of the programme in 2005-6 is supporting short-term alternatives for poor farmers who - for reasons of self-restraint or following eradication - have stopped growing opium poppy, and labourers who would otherwise work on the poppy crop.

4.4 DFID's livelihoods programme in 2005-6 will:

(i) support the GoA's efforts to mitigate the impact on those who have lost their livelihoods, through the expansion of key National Programmes into priority poppy-growing provinces

(ii) support initiatives and programmes to improve farm and off-farm opportunities for poor Afghan farmers and labourers to access sustainable legal income and employment, credit, productive and social assets, markets and other services

(iii) help generate an improved policy and planning environment for effective alternative livelihoods activity within a more comprehensive, coherent and integrated counter-narcotics strategy, including through supporting GoA to develop its own Alternative Livelihoods Implementation Plan

(iv) greater financial and technical support, delivered in a more coherent fashion, from other donors in support of the GoA Alternative Livelihoods Implementation Plan. 


\section{b) Economic Management and Aid Effectiveness}

4.5 The Government currently lacks the domestic revenue to cover its own recurrent costs, and is still developing economic management systems to raise, allocate and spend that revenue effectively and accountably. A strengthened public finance management system is central to the development and implementation of a National Development Strategy, which in turn is essential to effective government-led coordination of development activity. A continued move towards support directly to the budget (building on experience with the Afghanistan Reconstruction Trust Fund - ARTF) should promote Afghan ownership of a transparent, strategic and predictable domestic budget. It should also enable donor funding to be linked more closely to Government performance and development outcomes, allow for better budgeting and planning, and minimise perverse incentives not to increase domestic revenue.

4.6 GoA's strategic priorities for economic management ${ }^{5}$ are: i) implementation of effective, progressive, and equitable revenue collection procedures throughout the country to ensure sustainable economic management; ii) a modern annual budget formulation process, integrating current and capital expenditures, based on a medium-term expenditure framework; iii) a modern monetary system based on an effective commercial banking system, with currency and other financial operations controlled by an independent Central Bank. Increasing amounts of donor funds are being channelled through Government structures. Much needs to be done both to ensure the structures and systems are in place to spend these funds properly, and to increase further funding delivered through these mechanisms.

4.7 In the past two years DFID has focused its support on strengthening revenue collection and budget formulation, and contributions to the Government budget. Support has included three technical assistance projects with the Ministry of Finance, and participation in the World Bank-led Public Finance Management review. We have also committed $\varepsilon 240 \mathrm{~m}$ since 2002 in unearmarked funds to the ARTF (about half our funding), making us the single biggest donor to the GoA budget.

4.8 In 2005/06 DFID will continue to build on this support, consulting more closely with the Government to coordinate better with international partners. We will help GoA achieve its objectives on budget formulation and revenue mobilisation. We have committed $1150 \mathrm{~m}$ to the ARTF in unearmarked funds from 2005-8, giving GoA a rising contribution year-on-year and greater predictability in aid flows. We will start to negotiate a ten year development partnership between the UK and GoA, to better define our mutual commitment to poverty reduction and the way UK assistance will be provided. We have offered to host an international donor conference in January 2006 to help GoA present its interim ANDS to donors, and make the case for more effective and predictable aid, with a higher proportion of it going through the Government budget.

4.9 We will also provide some support to private sector development, mostly to improve the enabling environment for private sector growth. In the medium-term, this should help increase the Government's tax base and contribute to its revenue targets, as well as to economic growth more generally.

4.10 DFID activity in 2005/6 will focus on:

(i) technical assistance to GoA efforts to strengthen its fiscal and budget frameworks

(ii) improving donor dialogue on the use of ARTF funds and the Government budget, including better impact monitoring of development outcomes achieved through donor funding to GoA's budget

(iii) generating an improved understanding and use of aid instruments appropriate to Afghanistan's situation; including an assessment of the prospects for Poverty Reduction Budget Support, and input into the establishment and operation of the Counter-Narcotics Trust Fund

(iv) support to the GoA in the preparation and communication of its interim ANDS.

5. 1384 Public Investment Programme for PAREM, www.af 


\section{c) State-building}

4.11 The consolidation of a functioning and accountable public sector, and the establishment of strong and appropriate governance systems and the rule of law, are essential to fulfilling GoA's aims of restoring peace and stability, embedding democratic governance and regenerating economic growth (as set out in SAF). The emergence of effective state institutions - including in the security sector - is a precondition to the provision of the basic services that are vital to reducing poverty and sustainable economic growth. Effective state institutions are critical to investments in human and social capital (particularly in health, education and social protection) being financed and delivered.

4.12 The priorities for Public Administration Reform (PAR) ${ }^{6}$ are: i) the development of an efficient and productive civil service; ii) a restructured, smaller, competent and efficient government sector with strengthened policy making capacity; iii) ministries that are focused on delivering the core functions of government. Within GoA's broader state-building vision, the consolidation of professional, representative, affordable and accountable security sector institutions is also crucial.

4.13 DFID support to state-building to date has focused on: i) technical assistance to the institutions at the centre of government; ii) support to Security Sector Reform (SSR) and peace-building initiatives (mainly through funding development advisors in PRTs); iii) a major contribution to the Afghanistan Stabilisation Programme (ASP) to strengthen district administration, iv) support to the Presidential elections. Further assistance and support in these areas is vital to ensure progress continues. PAR and SSR will therefore remain priorities, with a major new programme of support to counter-narcotics institutions, and a realignment of our support to provincial stabilisation. We will explore further how we can strengthen ASP and/or find other ways to clarify roles and support the development of local government institutions. Parliamentary elections in September will mark another significant milestone in Afghanistan's political development. They need major international support (financial and technical) to ensure success.

4.14 In 2005/6 DFID activity will focus on assisting the GoA to:

(i) develop an efficient civil service capable of delivering the key functions of government, and strengthen government administration at national and sub-national levels

(ii) improve the quality of SSR, seeking to focus international support on establishing effective, co-ordinated, affordable and Afghan-owned security institutions

(iii) hold free and fair elections to the National Assembly and Provincial Councils, with good levels of participation and understanding of the election process by all parts of the population.

4.15 Forecast spend by focal area for $2005 / 6$ is outlined in chart 1 .

\section{Chart 1: Forecast spend by focal area $2005 / 6^{7}$}

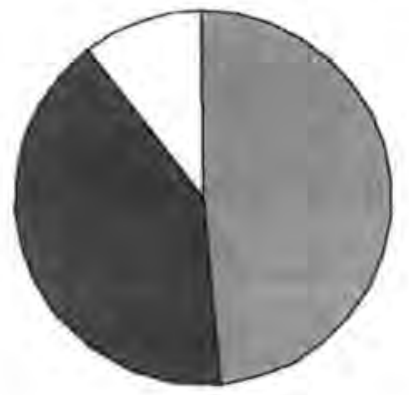

a Livelihoods $£ 49.5 \mathrm{~m}$

- Economic Management/Aid Effectiveness $£ 42.2 \mathrm{~m}$

$\square$ State-building $£ 10.7 \mathrm{~m}$

\footnotetext{
${ }^{6}$ Public Administration Reform (PAR) is a sub programme within GoA's Public Administration Reform and Economic Managemen (PAREM) programme, (1384 Public investment Programme for PAREM, www.af).

${ }^{7}$ This is based on over-programmed figures and totals $\$ 102.4$ million. Possible funding for the CNTF has been included in the Livelihoods total.
} 


\section{Resources}

5.1 At the Tokyo Conference in 2002, the UK pledged £200m over five years for development assistance to Afghanistan. At the Berlin Conference in March 2004 this pledge was increased to a total of $£ 500 \mathrm{~m}$ over the same time period. By mid-2005, £360m of this had been spent. Over the last three years the size of DFID's programme has grown substantially (see chart 2), and further increases are planned in future years. Our framework for $2005-2006$ is $190 \mathrm{~m}$ - this is a $15 \%$ increase over spend the previous year. These figures are more than the DFID resource allocation model would suggest for a country of Afghanistan's population. A higher level of assistance is justified by the fragility of the post-conflict situation, and the enormous backlog of investment needed after years of conflict and neglect by the international community and successive Afghan governments.

\section{Chart 2: DFID funding to Afghanistan ${ }^{8}$}

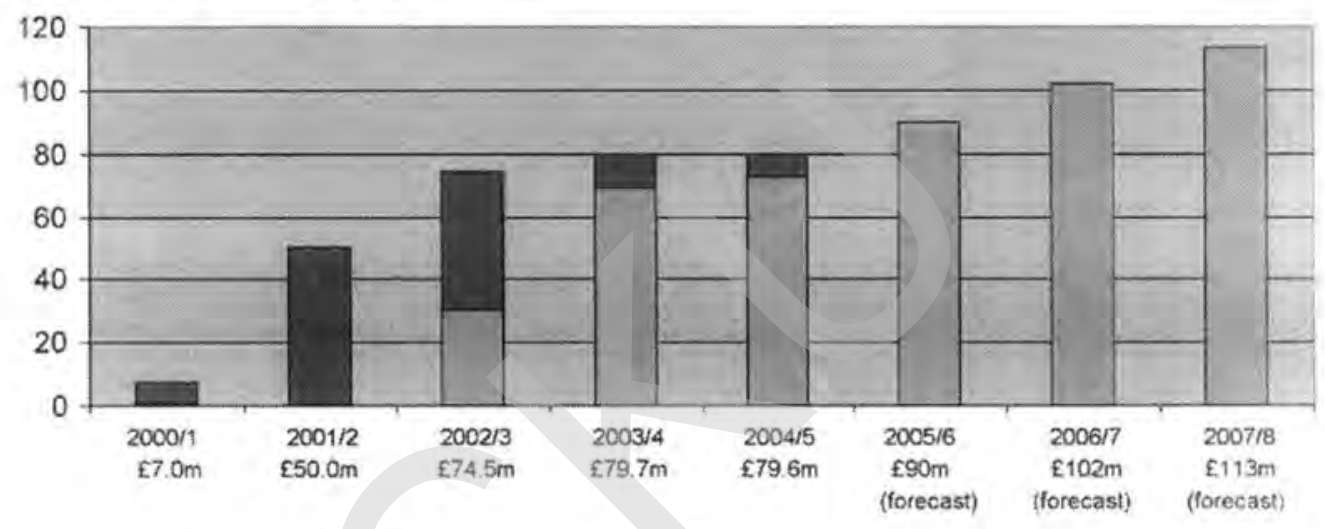

口 DFID Afghanistan development programme Humanitarian funding

5.2 DFID funding also assists Afghanistan through our global support to the EC, the UN and other multilateral organisations, and civil society organisations. The UK provides $19 \%$ of the European Commission's pledge of 1 billion euros in development assistance to Afghanistan from 2002-7, and $10.4 \%$ of the World Bank's pledge to Afghanistan. NGOs receiving core DFID funding who work in Afghanistan include CARE, Oxfam and Save the Children. Specific grants are also provided through DFID's Civil Society Challenge Fund (for example $£ 500,000$ for an NGO gender project to empower women's civil society networks), and from global DFID budget lines such as that for mine action, for which funding to Afghanistan in 2005/6 will be around $£ 2 \mathrm{~m}^{9}$.

5.3 DFID contributes to the Global Conflict Prevention Pool (GCPP), a trilateral mechanism bringing together expertise from the FCO, MoD and DFID to address the causes of conflict. The GCPP has spent $£ 57.5 \mathrm{~m}$ in Afghanistan to date, and has a $£ 20 \mathrm{~m}$ budget for Afghanistan in 2005/6, including for counter-narcotics activity. The UK is likely to spend around $£ 45 \mathrm{~m}$ on counter-narcotics in 2005-6, in addition to DFID's alternative livelihoods work.

5.4 These figures do not include other UK assistance to Afghanistan, including the costs of our military presence and support.

\footnotetext{
- Expenditure figures are provisional pending the publication of DFID's Statistics on International Development 2005.

s Funding for budget lines outside the main Afghanistan framework is included in past but not future spending figures.
} 


\section{Monitoring the impact of DFID activities}

6.1 Monitoring the impact of DFID activities on development outcomes in Afghanistan is a challenge. There is little baseline data and so far progress has not been systematically monitored and analysed. The I-ANDS process should help remedy this. Both donors and the GoA must be realistic about what can be achieved in the next few years; timeframes for achieving high-level targets such the MDGs must be long-term.

6.2 DFID objectives for 2005/6 and the key deliverables related to achieving these are at Annex 1 . These will be monitored twice yearly through DFID's divisional monitoring process, which links country objectives to UK Public Service Agreements.

6.3 During 2005/6 we will develop a more rigorous approach to monitoring the development outcomes that the DFID programme contributes to. Where possible, we will do this through the I-ANDS and other national processes.

6.4 We will put more effort into communicating the rationale for and impact of our programme, both in the UK and in Afghanistan.

\section{Risk assessment}

7.1 The main risks to DFID achieving these objectives are:

- Deterioration in security (probability - medium/low, impact - high): Current security risks already severely constrain the delivery of development assistance. Deterioration in security could destabilise the country, disrupt the reconciliation process and development of stable political institutions, and further limit development activity. Internal political processes may exacerbate this.

- Illicit opium economy undermines development (probability - medium, impact - high: It will take many years to eliminate the narcotics business. In the meantime those who profit from it will continue to pursue their own interests at the expense of state-building and broader economic development, often through corrupting government institutions and making successful development assistance very difficult.

- Weak capacity (probability - medium/high, impact - high): A lack of skilled capacity, especially in public administration, undermines the Afghan Government's ability to implement its programmes. Sustainable Afghan capacity can only be built gradually. Substituting international capacity in the meantime is expensive and sometimes counter-productive.

7.2 DFID is working with the rest of the UK Government, the international community and the Afghan Government to help improve the security situation, tackle the illegal narcotics business and build Afghan capacity for development. These are high impact and medium probability risks which are partly beyond our control. The programme already tries to mitigate all three of them through addressing some of their root causes. We also take specific precautions to manage the risk of insecurity to our own staff and operations.

7.3 These risks are partly a legacy of decades of instability and underinvestment. Although they represent daunting constraints, if they can be managed over time, the prospects for a viable state and gradual poverty reduction in Afghanistan are good. 


\section{ANNEX 1}

\section{Objectives and key deliverables for $\mathbf{2 0 0 5 / 6}$}

\section{Livelihoods}

\begin{tabular}{|c|c|}
\hline Objective & Key deliverables \\
\hline $\begin{array}{l}\text { Short-term quantifiable impact } \\
\text { on poor people who have lost } \\
\text { their livelihoods either through } \\
\text { self-restraint from planting } \\
\text { poppy, or eradication of their } \\
\text { poppy crops. }\end{array}$ & $\begin{array}{l}\text { - National Emergency Employment Programme delivering its } 1384 \text { strategy and providing } 5.8 \\
\text { million labour days cash for work and corresponding rural infrastructure (ongoing). } \\
\text { - National Solidarity Programme expanding its operations to } 50 \text { new districts in the seven main } \\
\text { poppy-growing provinces (ongoing). } \\
\text { - A second lending window of the Microfinance Investment Services Facility for Afghanistan - fo- } \\
\text { cusing on poppy-growing provinces - up and running by August } 2005 \text { and piloting refinancing } \\
\text { models for opium debt by September } 2005 \text {. } \\
\text { - DFID support to quick impact activities with the Ministry of Agriculture agreed with GoA by end } \\
\text { July } 2005 \text {. }\end{array}$ \\
\hline $\begin{array}{l}\text { Farm and off-farm opportunities } \\
\text { improved for Afghan farmers } \\
\text { to access sustainable legal } \\
\text { income and employment; } \\
\text { productive and social assets; } \\
\text { markets and other services. }\end{array}$ & $\begin{array}{l}\text { - Results of first year trials under Research into Agricultural Livelihoods Fund identifies at least } \\
6 \text { new crops or technologies with potential for scaling up among current or potential poppy } \\
\text { farmers by December } 2005 \text {. } \\
\text { - Alternative Agricultural Livelihoods Programme establishes institutional platform for strategy, } \\
\text { capacity building and coordination, and inception phase charts } 5 \text { year plan for the programme } \\
\text { by March } 2006 \text {. } \\
\text { - Badakhshan NGO Development Forum leads to increased number of farmers accessing high } \\
\text { quality seeds; increased number of people trained and adopting new income generating activi- } \\
\text { ties; improved support by NGO forum for provincial and district government. } \\
\text { - Improved farm and off-farm opportunities tested and implemented through Sustainable Aiter- } \\
\text { native Livelihoods in Eastern Hazarajat programme by March } 2006 \text {. }\end{array}$ \\
\hline $\begin{array}{l}\text { Enhanced policy and planning } \\
\text { environment for effective } \\
\text { alternative livelihoods activity, } \\
\text { within a more comprehensive, } \\
\text { coherent and integrated GoA } \\
\text { counter-narcotics strategy. }\end{array}$ & $\begin{array}{l}\text { - Alternative Livelihoods Implementation Plan (ALIP) endorsed by President Karzai by July } 2005 . \\
\text { - A prioritised short-term AL plan approved and integrated with ALIP by July } 2005 . \\
\text { - A comprehensive, coherent GoA agricultural masterplan developed by October } 2005 \text { (facilitated } \\
\text { by DFID's advisory support to Ministry of Agriculture). } \\
\text { - A draft land policy and recommendations for land administration reform prepared by Septem- } \\
\text { ber } 2005 \text {, which takes into account access rights for poor people, conditions to attract invest- } \\
\text { ment, and the overarching context of the opium economy. } \\
\text { - A long-term integrated counter-narcotics plan agreed by March 2006, which reflects the im- } \\
\text { portance of sequencing, maintains a sound evidence base, and provides the means to harmo- } \\
\text { nise donor support. }\end{array}$ \\
\hline $\begin{array}{l}\text { Increased engagement and } \\
\text { financial and technical support } \\
\text { for alternative livelihoods from } \\
\text { other donors, delivered in a } \\
\text { more coherent fashion. }\end{array}$ & $\begin{array}{l}\text { - A successful international donor conference in January } 2006 \text { raises over } \$ 50 \mathrm{~m} \text { for GoA's Coun- } \\
\text { ter-Narcotics Trust Fund. } \\
\text { - An effective ministerial lobbying effort helps mobilise new resources for counter-narcotics } \\
\text { (ongoing). } \\
\text { - Understanding of alternative livelihoods enhanced and its contribution to the wider counter- } \\
\text { narcotics effort (and limitations) appreciated (ongoing). } \\
\text { - Continued advocacy with major donors and policy-makers for evidence-based planning and } \\
\text { implementation. }\end{array}$ \\
\hline
\end{tabular}




\section{Economic Management and Aid Effectiveness}

\begin{tabular}{|c|c|}
\hline Objective & Key deliverables \\
\hline $\begin{array}{l}\text { GoA fiscal and budget } \\
\text { frameworks strengthened } \\
\text { to achieve i) } 2005 / 6 \text { revenue } \\
\text { target of } \$ 333 \text { million; and ii) } \\
\text { full spend of a comprehensive, } \\
\text { poicy-based budget. }\end{array}$ & $\begin{array}{l}\text { - Budget Directorate priorities for } 2005 / 6 \text { agreed, with clear steps on how DFID and others can } \\
\text { assist to deliver on them. } \\
\text { - Tax and customs projects aligned with MoF review of technical assistance and Government } \\
\text { objectives on revenue policy and administration. } \\
\text { - Diagnostic study on EM completed and presented as a tool to guide future support to EM, with } \\
\text { clear links with other parts of the programme. } \\
\text { - Clear action plan on Public Finance Management reform agreed between donors and Government. } \\
\text { - Successful development and implementation of a private sector development policy. }\end{array}$ \\
\hline $\begin{array}{l}\text { Interim Afghan National } \\
\text { Development Strategy } \\
\text { completed, with clear } \\
\text { framework for donor } \\
\text { coordination and } \\
\text { harmonisation, and increased } \\
\text { donor commitment to a } \\
2006 / 7 \text { core budget reflecting } \\
\text { 1-ANDS priorities. }\end{array}$ & $\begin{array}{l}\text { - Clear recommendations to Government on content and process for I-ANDS according to GoA } \\
\text { timetable. } \\
\text { - Progress on Paris Declaration on harmonisation achieved, including clear benchmarks for do- } \\
\text { nor-Government policy dialogue, and harmonised performance indicators for donor support } \\
\text { directly to the budget which track development impact of budget support. } \\
\text { - Ten-year Partnership Framework Arrangement signed between Governments of the UK and } \\
\text { Afghanistan by January. } \\
\text { - Successful international donor conference in January } 2006 \text { secures greater support for the } \\
\text { core budget. } \\
\text { - Counter-Narcotics Trust Fund established, with capacity in Ministry of Counter-Narcotics and } \\
\text { Ministry of Finance to allocate and manage CNTF funds within the core budget process. } \\
\text { - Comprehensive analysis of the prospects for Poverty Reduction Budget Support through co- } \\
\text { funding of World Bank direct budget support operation. } \\
\text { - Recommendations, and if appropriate further support, to GoA on actions needed to strengthen } \\
\text { Afghanistan's statistical base through implementation of the Statistical Masterplan. }\end{array}$ \\
\hline
\end{tabular}

\section{State-building}

\begin{tabular}{|c|c|}
\hline Objective & Key deliverables \\
\hline $\begin{array}{l}\text { Public Administration Reform } \\
\text { (PAR) at the national and sub- } \\
\text { national levels accelerated, } \\
\text { with support delivered in } \\
\text { a more coordinated and } \\
\text { effective way. }\end{array}$ & $\begin{array}{l}\text { - A plan for harmonisation of support to capacity building and PAR at national and sub-national } \\
\text { level, which reflects the importance of sequenced donor inputs, in place by end } 2006 \text { (in sup- } \\
\text { port of the l-ANDS). } \\
\text { - Advocacy with partners to ensure key constraints to effective PAR in relevant government } \\
\text { institutions effectively addressed (ongoing). } \\
\text { - Voter education programme ensures that population well informed and better able to partici- } \\
\text { pate in electoral process by September } 2005 \text {. } \\
\text { - Coherent and effective technical support strengthening capacity for implementing the core } \\
\text { functions of government in key Ministries. }\end{array}$ \\
\hline $\begin{array}{l}\text { Afghan-owned security } \\
\text { institutions strengthened, and } \\
\text { supported by a coherent and } \\
\text { integrated donor approach } \\
\text { to jecurity sector reform at } \\
\text { national and provincial level. }\end{array}$ & $\begin{array}{l}\text { - Strategic assessment of UK conflict prevention activities, and an outline approach for future } \\
\text { support to security sector reform and peace-building, agreed by December } 2005 \text {. } \\
\text { - Improved alignment of the international military deployment to meet government security sec- } \\
\text { tor reform priorities at national and provincial level, through deployment of additional Develop- } \\
\text { ment Advisers in NATO ISAF HQ and Helmand by October } 2005 \text {. } \\
\text { - Advocacy with key partners (GoA, major donors, and other UK departments) to develop a more } \\
\text { co-ordinated approach to security sector reform and peace-building in Afghanistan (ongoing) }\end{array}$ \\
\hline
\end{tabular}


ANNEX 2

\section{DFID Afghanistan Expenditure Forecast 2005/06}

\begin{tabular}{|c|c|c|}
\hline Programme/project & $\begin{array}{c}\text { Total } \\
\text { allocation } \Sigma m\end{array}$ & $\begin{array}{c}\text { Forecast spend } \\
2005 / 06 \mathrm{Em}\end{array}$ \\
\hline \multicolumn{3}{|l|}{ Livelihoods } \\
\hline NEEP - National Emergency Employment Programme & 18.00 & 18.00 \\
\hline NSP - National Solidarity Programme & 17.00 & 9.00 \\
\hline MISFA - Micro-finance Investment Support Facility in Afghanistan & 20.00 & $7.00^{10}$ \\
\hline *Fertiliser and seed distribution & 3.00 & 3.00 \\
\hline Badakhshan Community Stabilization Project (IOM) & 3.00 & 2.50 \\
\hline Research into Alternative Livelihoods Fund & 3.00 & 1.70 \\
\hline 2004 GoA Drought Appeal (UNDP) & 3.00 & 1.33 \\
\hline Eastern Hazarajat Alternative Livelihoods Project (UN FAO) & 3.77 & 1.13 \\
\hline Alternative Agricultural Livelihoods Programme (UN FAO) & 3.75 & 1.10 \\
\hline Badakhshan - Aga Khan Development Network AL programme & 3.50 & 1.06 \\
\hline TA to MRRD and MAAHF on Sustainable Livelihoods & 2.10 & 0.70 \\
\hline Various other & 1.21 & 0.97 \\
\hline Sub total: & & 47.49 \\
\hline \multicolumn{3}{|l|}{ Economic Management/Aid Effectiveness } \\
\hline Afghanistan Reconstruction Trust Fund (unearmarked funds) & $\star 240.00$ & $35.00 " 11$ \\
\hline "Counter-Narcotics Trust Fund & 20.00 & 2.00 \\
\hline TA to Ministry of Finance on Tax Administration & 4.40 & 2.02 \\
\hline TA to Ministry of Finance on Customs Administration & 4.50 & 1.70 \\
\hline TA to Ministry of Commerce on Private Sector Development & 3.99 & 1.30 \\
\hline TA : 2 Ministry of Mines and Industry & 3.85 & 1.20 \\
\hline TA to Ministry of Finance on Budget Formulation & 2.60 & 1.02 \\
\hline Sub total: & & 44.24 \\
\hline \multicolumn{3}{|l|}{ State-building } \\
\hline Afghanistan Stabilisation Programme & 20.00 & -12 \\
\hline Support to Parliamentary/Provincial Elections & 3.60 & 3.60 \\
\hline TA to MCN/Mol etc to strengthen Counter-Narcotic Institutions & 12.55 & 2.90 \\
\hline Support to Development Advisers in Provincial Reconstruction Teams & 5.00 & 1.60 \\
\hline TA to the Civil Service Commission (IARCSC) for Public Admin Reform & 1.67 & 0.84 \\
\hline Support to the Office of the President's Spokesman & 1.50 & 0.50 \\
\hline Afghanistan Research and Evaluation Unit: Drivers of Change research & 1.00 & 0.50 \\
\hline "TA to Centre of Government institutions & 3.00 & 0.30 \\
\hline Support to World Bank on Governance and Public Admin Reform & $* 0.45$ & 0.26 \\
\hline Support to British Agencies in Afghanistan Group & 0.40 & 0.18 \\
\hline Sub total: & & 10.68 \\
\hline Total forecast expenditure & & $102.4^{13}$ \\
\hline DFID aid framework for Afghanistan 2005/6 & & $90.00^{14}$ \\
\hline
\end{tabular}

10 Total for 1384 is $£ 8 \mathrm{~m}$ - includes $£ 1 \mathrm{~m}$ at end of UK 2004/5 FY

11 Total for 1384 is $£ 45 \mathrm{~m}$ - includes $£ 10 \mathrm{~m}$ at end of UK 2004/5 FY

12 Contribution made and accounted for in March 2004, not yet fully disbursed

13 Total for 1384 is $£ 113.4 \mathrm{~m}$ - includes $£ 11 \mathrm{~m}$ at end of UK 2004/5 FY

14 Some over-programming in expectation of slippage. Forecasts are not firm annual commitments

- Project or extension not yet approved - not a commitment 


\section{DEPARTMENT FOR INTERNATIONAL DEVELOPMENT}

DFID, the Department for International Development: leading the British government's fight against worid poverty.

One in five people in the world today, over 1 billion people, live in poverty on less than one dollar a day. In an increasingly interdependent world, many problems - like conflict, crime, pollution and diseases such as HIV and AIDS - are caused or made worse by poverty.

DFID supports long-term programmes to help tackle the underlying causes of poverty. DFID also resnonds to emergencies, both natural and man-made.

DFID's work forms part of a global promise to

- halve the number of people living in extreme poverty and hunger

- ensure that all children receive primary education

- promote sexual equality and give women a stronger voice

- reduce child death rates

- improve the health of mothers

- combat HIV and AIDS, malaria and other diseases

- make sure the environment is protected

- build a global partnership for those working in development.

Together, these form the United Nations' eight 'Millennium Deveiopment Goals', with a 2015 deadline. Each of these Goals has its own, measurable, targets.

DFID works in partnership with governments, civil society, the private sector and others. It also works with multilateral institutions, including the World Bank, United Nations agencies and the European Commission.

DFID works directly in over 150 countries worldwide, with a budget of some $\$ 4.6$ billion in 2005 . Its headquarters are in London and East Kilbride, near Glasgow.

Produced for DFID by Copyprint UK Ltd, 750 08/05, ISBN 186192724 X, Crown copyright 2005 
Downloaded on $4^{\text {th }}$ October, 2005

European Commission "Country Strategy Paper for Afghanistan: 2003-2006" Brussels (February 2003), available at:

http://europa.eu.int/comm/external_relations/afghanistan/csp/03_06.pdf

Similar to DFID's planning document, this document lays out the EC's humanitarian aid programs for Afghanistan over 2003-2006. It reviews the current situation and attempts to align its funding priorities to those enumerated by the ATA in the NDB. It also includes 'benchmarks' which it suggests should be applied to make sure that humanitarian aid will have the desired impact 